\title{
TO BE AND HOW TO BE: INSIDES OF PROGRESS AND FAILURE IN LANGUAGE LEARNING
}

\author{
NGUYỄN TRƯỜNG SA \\ Industrial University of Ho Chi Minh City; \\ nguyentruongsa@iuh.edu.vn
}

\begin{abstract}
This study investigated deeply into what happened when a language learner made failure and success. The question is how and what learners do to make improvements and achievements and/or to turn their learning results worse. Adopting grounded theory methodology and ethnographic perspective with prolong observations and interviews as the basis of data collection and analysis, the researcher studied the learning stories of 8 participants in 24 months to build up a general formula explaining how improvements and achievements operate. Motivation and autonomy were classified as the two central and most stable constructs in a holistic model containing numerous changing affective factors. Results showed that it is not really because of any single change in any individual factor/construct, but the operation of this whole model shapes the success and failure in language learning.
\end{abstract}

Keywords. grounded theory, achievement and failure, motivation, autonomy, affective factors

\section{BACKGROUND OF THE STUDY}

Since the late $20^{\text {th }}$ century, the role of learning as a critical and inseparable component in the process of teaching and the learners as active partners in shaping their own learning process have been accepted by a number of scholars and researchers in the field of language education (Rubin 1979; Nunan 1988; Ellis \& Sinclair 1989; Rubin \& Thompson 1994; Brown 1991; Brown 2000; Cook 2001). The common conclusion has been that teachers should enable learners to begin to take charge of their learning and use techniques which approach learners as individuals. In this general trend, how to teach less competent learners was one of the centered topics for doing research. Reiss (1981) stressed that:

Can our knowledge of the successful language learner aid the unsuccessful language

learner? In order to answer this question, we must first establish what constitutes a

successful language learner and, second, determine what strategies and techniques

the successful language learner employs. (p. 121)

Reiss's argument seems to be the best summary in the last decades to help low competent language learners moving ahead. According to the rationale of the past studies (Gardner \& Lambert 1959; Rubin 1975; Porte 1988; Ehrman \& Oxford 1995; Takeuchi 2003; Magogwe \& Oliver 2007), if we understand more about what the successful learners did, we would be able to teach these "secrets" - the techniques, devices which a good learner may possess to acquire knowledge - to poorer learners to enhance their success record; As a result, the differences between the good learner and the poorer one were expected to be lessened (Rubin 1975). From this reason, while most studies investigated into good or successful language learners, just a few scholars (Porte 1998) concentrated on figuring out what unsuccessful learners' process of learning. According to Rubin (1975), the questions have been posted around the following questions:

- What is it that makes for a good learner?

- Why are some learners successful?

- How do learner differences relate to effective language learning?

- How can learners manage aspects of different learning situations?

Results from this persistent endeavors of the scholars has showed that higher or lower motivation (Gardner \& Lambert 1959), a strong combination of motivation, aptitude, and opportunity to use language (Rubin 1975), or a more complex mutual relation between learners variables (motivation, age, strategies, styles, gender, beliefs, etc.) and learning variables (vocabularies, grammar, functions, etc.) (Griffiths 2008), and identity (Harklau 2000) are the centre causes of the differences. Besides, good language 
learners have been described as more willing and accurate guessers, have stronger drive to communicate and learn from communication, more time to practice, more closely on monitoring their progress, and are able to attend to both form and meaning (Rubin 1975). However, up to now no study has PROVED that weak learners did make progress by adopting the skills and strategies drawn from the successful ones. Although the scholars have tried to argue that low English proficiency identity can be changed and improved by this way, very few and unclear evidences were posted. In their literature review, Williams and Burden (1997) summarized that the past researches have been mainly concerned with measuring, labeling, and grouping people according to perceived similarities. The findings have been of limited practical value because they do not inform us how we can help any individual to become a more effective leaner. As identities of individual language learners are constantly shaped and reshaped, continually recreated and negotiated by particular educators and students working in specific classrooms, institutions, and societies (Peirce 1995; McKay \& Wong 1996; Norton 1997; Harklau 2000), it would be more practical to investigate how learners construct their own identity during their learning process. Therefore, this study neither investigates more into how learners were different nor experiments how weak learners adopt "new" ways of learning, instead, the researcher concentrates on how and what learners do to make improvements and achievements and/or to turn their learning results worse.

\section{RESEARCH METHODS}

As a result of the earlier argument, the author needs a research method that sees how people change rather than how they stay the same. The method should report how learners take personal control over their own learning and give space for teaching and learning implications and interventions. Therefore, this study adopts grounded theory methodology and ethnographic perspective with prolong observations and interviews as the basis of data collection and analysis.

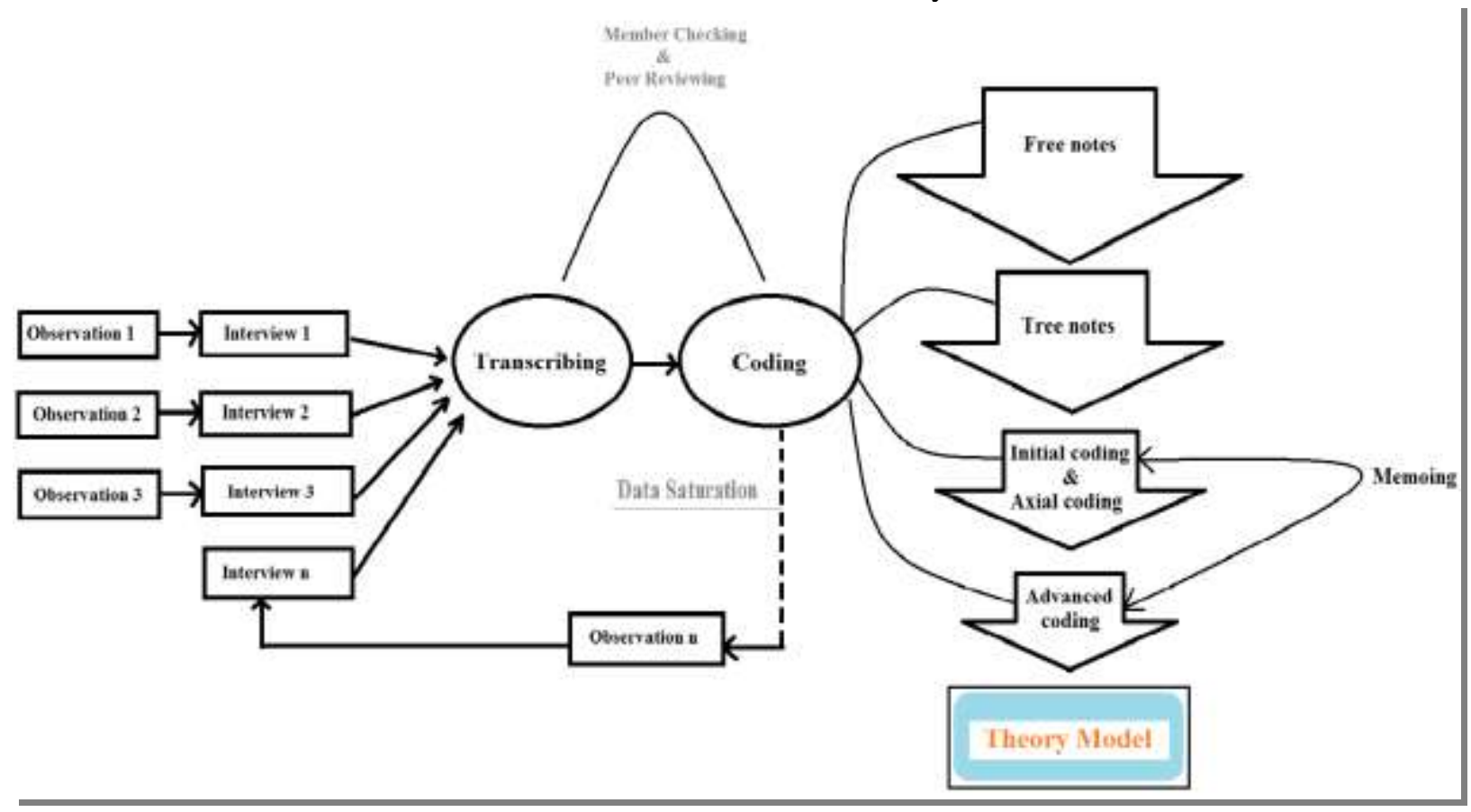

Figure 1. The grounded theory process

Fieldwork in the study took place at the faculty of foreign languages, Ho Chi Minh City University of Industry and HUTECH University in Vietnam. Eight students participating in the study (4 male students and 4 female students) were enrolled in a four-year-long bachelor of art in English language course. From the volunteer students, eight were chosen based on their English subject grade in the university entrance exam; 4 of them were at average grade while the others were graded above average. The researcher chose them as they were more potential to make clearer progress when compared to more excellent or less competent learners. The goal of this purposive sampling method was to enable the 
researcher to seek out learners who were able to help answer the research questions and, thus, offered the best chances for creating solid theory. In their BA course, the participants were mainly trained English grammar and lexis, and four macro language skills in the first 5 semesters. Then, subjects such as English literature and cultures, teaching and learning theory, and translation and interpretation skills were added in the rest three semesters of the course. Following an inductive system for generating interrelated hypotheses grounded in the empirical as specified in grounded theory (Glaser \& Strauss 1967; Strauss \& Corbin 1990, 1994, 1998; Charmaz 2000), the data were collected and analyzed from the second to the fifth semester. Strictly followed the steps of grounded theory research (Glaser \& Strauss 1967; Glaser 1978, 1992, 1998), one of the researcher's central tasks in 24 months was collecting rich qualitative data from non-participant classroom observation, in-depth and stimulated recall interview, and field note resource. Meanwhile, the other core task was to generate theory by constantly comparing data, coding, relating and confirming concepts, and member checking. An expert qualitative researcher also conducted the peer review by examining the interview transcripts, coding sheets, and the integrated model of the findings. His review identified the analysis as being completed in a logical and systematic manner, and the coding and categorizing processes were accurate based on the stimulated recall interview data. Until no new or relevant data are emerging regarding a category and the relationships amongst categories are well established, the researcher verificationally built on a theory for the research problem. The following diagram summarized the grounded theory process of the current research study.

\section{Results}

Results of this study showed that all the participants have made learning progress at different speeds and in different aspects of language learning. Each individual picture of progress has been influenced strongly by a number of different ready-to-change factors and clusters of factors.

\subsection{Situated motivation}

The extent to which the participants have made effort depended highly on the teaching methods of the teacher of the subject and/or their rapport with that teachers, their interpretation of the value of classroom activities, and the opportunity for them to practice English in class. All of the participants showed that they "would study harder" in some particular subjects and "tend to be lazier" in some others. From their explanation, the reason could relate much more strongly to how they observed the teacher taught in class than the teacher's reputation or academic qualification; Most of their reasons related to this factor can be categorized into teachers' classroom techniques such as instruction and feedback giving and tasks adjustment and arrangement. Although each learner may not have enough pedagogical knowledge to evaluate or criticize his/her teacher's methods, he/she could "feel" the effectiveness of the lesson or ways of learning/teaching based on their learning experience, expectation, and beliefs about language learning. Therefore, each of them always had their personal parameter to see the extent to which an entire lesson or a particular on-going activity relevant to their learning purposes. Besides, the participants performed better in some particular subjects when there was a better rapport between them and the teachers compared to teachers of other subjects. This factor did not, of course, arise by itself; it was founded through daily effective and interesting lessons and the teachers' willingness to show their consideration and enthusiasm in teaching. The longitudinal qualitative data of this study showed that the more the participants were motivated in a subject, the more seriously they cared of learning and higher achievements they got (based on their own evaluation). Interestingly, factors that motivated them tightly situated on on-going daily teaching and learning activities and through direct interaction between the teachers and the learners.

\subsection{The evolution of learning goal}

Interestingly, after 3 years in the program, the participants' goals of learning did not remain as similar as goals when they started. This step by step evolution has been shaped and reshaped by their future plans, parents, alumni, as well as their financial status. While most of them started with a very general and vague goal such as becoming a teacher, a translator, or a tour guide, these goals have been described to be more practical and specific. The participants have turned their general goals into more detailed plans of kinds of jobs they would do after graduation. They used to portrait their future based on their parents guidance, their dream and intuition, but the university classroom and reality has taught them 
to observe how the alumni worked, how to take their own responsibility for the future, and the current financial status to decide how to learn and what to do in the future. For instance, one participants used to think of being a translator changed the plan to earn a Master Degree in language teaching after graduate to pursue education career. He has realized that language teaching is more interesting and brings more financial benefits while translation is a more challenging job. Therefore, he invested more time and effort in subjects related to teaching methodology. As a results, his achievement in pedagogical subjects became more and more promising while his marks and skills on translation remain more stable. On the other hand, another participant had to share his school time to a part-time job in a tour seller to earn enough money for her schooling, and then she decided to save more time on speaking ad other soft skills to prepare herself as a tour guide or operator. After three years, another participant identified himself as a speaker for an international IT company. He argued that English is simply a tool for communication rather than a job, thus he just tried to equip a professional speaking skill. Instead, he was taking part in a computer school as in his argument, technology is his future main field of job.

\subsection{Supportive level of environment}

Learning environment was the next key influential factor to the learning progress of the learners. To make clearer progress, the learning context tended to be more "learner friendly" - which means: to support learners to learn in the light of both internal/mental and external/physical levels. Regarding internal/mental factor, when the participants felt safe and confident, they were more willing to participate. Only when they saw no or little threatened and negative evaluation and feedback from the people around, did they start to contribute their parts and as a result, they were more critical on the value of the lesson and what they were doing. On the other hand, the external/physical learning context such as the availability of modern classroom equipments, teaching aids, classroom e-learning devices, internet, etc. made learning a lot easier for them. In their reasons, these facilities freed themselves from the burden of taking notes and memorizing to spend more time of task preparation and critical thinking in class. They all showed a very discouraged attitude to some traditional classes with purely paper and course book activities conducted by teachers trying to "feed" them knowledge. One participant argued that "the modern devices make learning effective as the way they make our life convenient. I want to focus only on learning; it is the job of the school to give me the most convenient and effective ways of doing it" (f3-p716-Jul.2014). When the environment was more learning-supportive, each lesson became a lot more fruitful and less stressful to the learners.

\subsection{Perceived values of achievements}

One of the core factors that motivated and boosted the learners to learn was a clear recognition of achievements. In other words, they wanted to see the outputs of their learning efforts, and remarkably, these positive outputs must come early. Based mainly on their teachers' and classmates' feedbacks, they realized their progress and thus, became more confident with their ways of learning. At the beginning of the course, they might try working with some different strategies or methods learned from the teacher of the subject, or other books or experts; however, most of which would be left aside very early after that to make room for other strategies/methods attempts. Until they could see a clear and quick effect, did they adopt the strategies and applied them more widely to other subjects. In this process, teachers' evaluations through better marks, recommends and positive feedbacks for classroom participation were always a key motivational energy for them to get a long. Beside that, evaluations and judgments from other classmates on their performances was also a reliable channel of information for them to assess themselves. These factors were observed not only among different subjects that an individual learner took but also among the participants themselves. For each of them, finding a suitable method to learn was the secret of improvement. As a result, some participants could gain a lot of achievements in some particular subjects or skills but remained at the same level of competence or were left behind in other skills or subjects.

\subsection{Self-efficacy}

Beside evalations from teachers and friends, each learner also had his/her own criteria to assess their personal success. Based on past learning experiences and habit, the learners had formed personal strong beliefs on "indicators" of successful and unsuccessful language learning. Then, they localized themselves into this list of indicators, often estimated the strenghts and weaknesses of themselves, and acted 
according to these perceptions. Each of them was the person who had the clearest understanding of what they had done, what they had achieved, and where their failures had been; thus, they claimed that these successful or unsuccessful experiences affected them strongly when planning for any action both inside and outside class. A participant highlighted that "what improvements are? you must know where you were yesterday, and whether today you are at the same position or go ahead. Simply to me, I am happy when today I can do something I could not do yesterday, today I can learn new lessons. Therefore, it is extremely important to know what you can do and what you cannot do today" (m2-p21-20-May.2014). According to another participant, "learning to me is not a war with my classmates, it is a fight between me and myself. I do not compete with other people as I know they are aslo trying and making progress with their own strengths... I just try to fix my own mistakes" (m3-p35-3-Jan.2015). However, if they felt that the friends around were making progress faster, they became doubt with the adopted strategies/methods of learning; and that is the issue related to experiencing with learning methods discussed in the previous section.

\subsection{An Integrated Model}

Completing the advanced coding procedures on the data allowed to generate the following propositions.

- Motivation change and autonomy boost are the two most central impetuses to decide the quantitative and qualitative features of learning progress.

- These two central factors have cause and effect relationship; both of which are shaped by five key inner factors of the evolution of learning goal, supportive level of environment, situated motivation, self-efficacy, and perceived values of achievement.

- Each of these five factors is formed by a number of more outer/surrounding factors arising during the learning process.

The ProfessSA model below visualizes how these factors relate and propose a theory ways to make success or get failure in learning a language for adult learners.

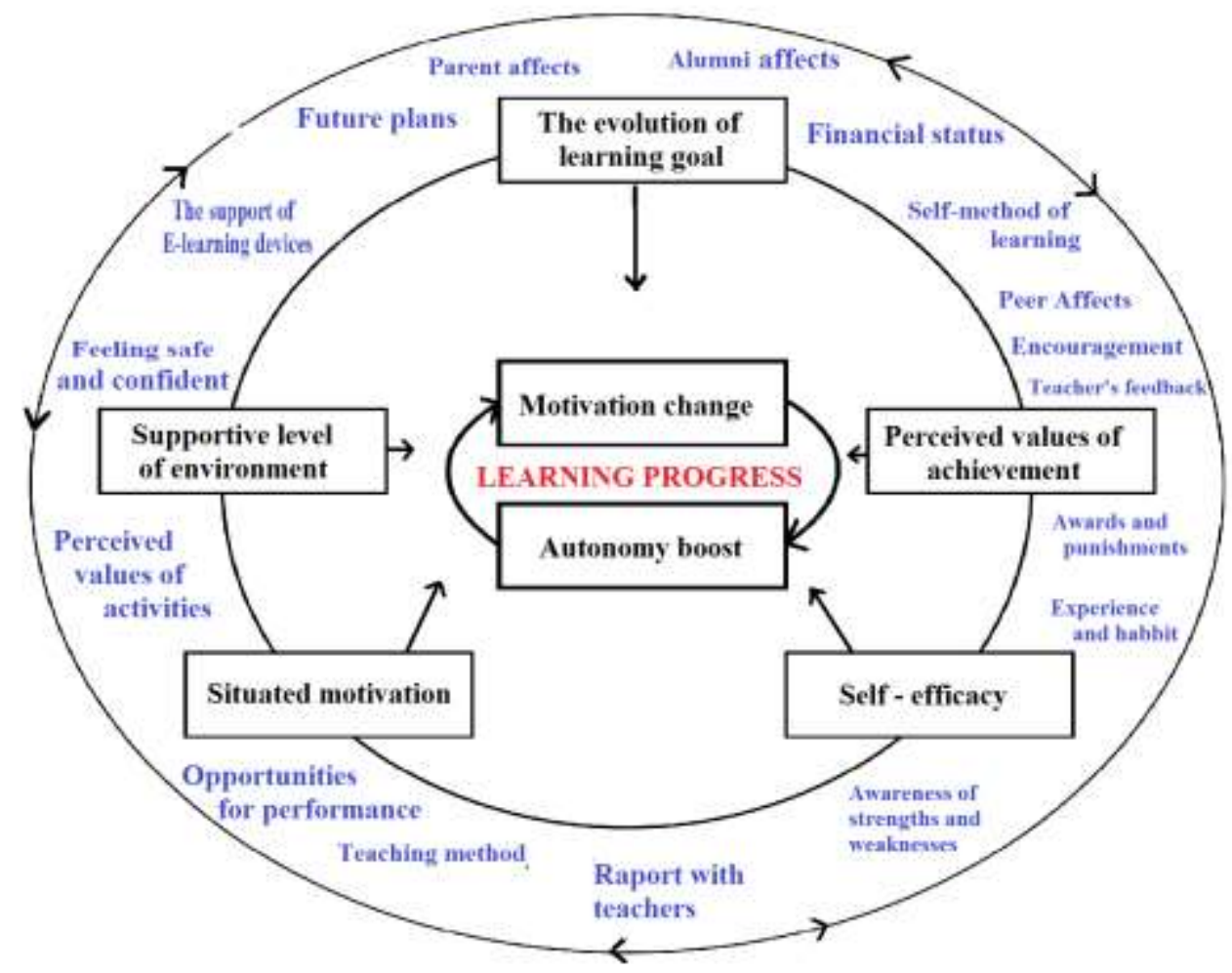

Figure 2. ProfesSA model of language learning progress

To interpret this model, it is important to note that the borders were there for visualizing, in some particular circumstances they may not necessary exist. Besides, although the outer factors most directly 
affect the nearest inner factors, they are not necessary to remain stably; instead, they may evolve themselves and circulate around the inner factors. These characteristics are important as they regulate how learners change.

\section{DISCUSSIONS}

\subsection{Situated motivation}

L2 motivation is a complex, multifaceted construct and the crucial central role of motivation in shaping the success of failure has been discussed intensively in the literature of language learning. However, the previous studies have not concluded on issues such as: which framework of motivation is more applicable, teachers should or should not help learners to change their motivation, should or should not teach learners with 'instrumental', 'integrative', 'intrinsic', and 'extrinsic' motivation differently. Besides, it has not been clear whether different learners are motivated in the same ways, by the same activities in class. Therefore, lists of motivations and theories underlying motivation themselves are not readily applicable; what teachers usually want to know is how they can intervene, that is, what they can actually do to motivate their learners. Based on the results of this study, defining and categorizing motivation are less practical and applicable to language teaching and learning than examining how learners are motivated in on-going classroom activity. Motivation was observed as being unstable, and classroom (situated) situation accounted a significant part in motivating learners. This kind of motivation is the initial foundation for changes in the complex structure of individual motivation in language learning.

\subsection{The evolution of learning goal}

Learning goal is always one of the central components in defining learning motivation (Gardner \& Lambert 1959, Williams \& Burden 1997, Kormos et al. 2011, Kormos 2012). Besides, this key component was proven as a reliable predictor of motivation to learn (Colquitt \& Simmering 1998, Pintrich 2000). These scholars shared the argument that goal orientation correlatively facilitate the maintenance of motivation patterns, shape academic performance, and decide the level of cognitive outcomes. Longitudinal studies in the literature have examined intensively into motivation construct and it has been widely known that motivation is not stable over time, domains, and contexts. However, the stability of learning goal has not been closely investigated so far in the light of its relation to the stability level of language learning motivation and autonomy. Results of this study confirmed that learning goal was a flexible construct and any goal changing could initialize and affect the status and structure of ongoing motivation and level of autonomy in the process of language learning. Therefore, it is worth to note for any language educator as individual's learning goals are varied and their change may be unpredictable and are influenced by a number of factors arising both inside and outside class.

\subsection{Supportive Level of environment}

Learning a foreign language is never an easy job. It always requires countless personal effort and investment to anybody who wish to master a new language. To a large number of learners, the learning route often goes with painful and unsuccessful feelings. According to Stern (1983), a student learning a new language faces three major problems or dilemmas: 1) the problem of dominance of the first language as reference system as opposed to the new underdeveloped reference system; 2) the psychological impossibility of having to pay attention simultaneously to linguistic forms and communication 3) the problem of having to choose between rational and intuitive learning. In addition to the three problems mentioned by Stern, the student must also face the overall dichotomy of the desire to communicate vs. the frustration and stress of the inability to do so (Reiss 1981 121). Therefore, the history of language teaching has produced a diversified teaching methods and techniques to improve the effectiveness of teaching and learning. The methods may be varied and employed different perspectives, procedures, and/or techniques, but most of which have shared a permanent view on the role of a comfortable and positive environment of learning. This study confirmed the key role of supportive lessons in contributing into the learning success. If challenges and obstacles are inevitable and originate from internal, psychological, and natural factors of the language and language learning, the external and more 
manageable factors should be as much positive as possible. Learners at any age and in any situation must be put in an environment in which they feel safe, convenient, and encouraged.

\subsection{Self-efficacy}

Self-efficacy is described as people's evaluation and prediction of their capabilities to complete a task successfully (Bandura 1989). Students with a strong sense of personal learning efficacy willingly undertake challenging tasks, invest greater effort in the completion of those tasks, and show increased persistence with obstacles (Vuong, Brown-Welty, \& Tracz 2010). In the literature, self-efficacy has emerged as a strong predictor of language learning achievement (Graham 2006; Vuong et al. 2010). According to Bandura (1989), four main sources of self-efficacy are (1) learners' past performances, (2) observation of how well others do, (3) verbal persuasion from others, and (4) somatic and emotional states. Therefore, past and current judgment and assessment from teachers and classmates are indeed key contributor to self-efficacy development; they can directly strengthen or threaten this individual selfconcept. This study re-stressed the role of this factor, connected it to other neighbor factors, and highlight its effect on founding the more central sources of learning achievements. Self-efficacy has been proved as one of the initial change that shaped motivation and autonomy in language learning.

\subsection{Perceived values of achievements}

While self-efficacy relates more closely to "I can do", achievement perception describes individual recognition of his/her progress or "I achieved", "I gained" and "I am deserved". In this study, this construct represents learners' satisfy-level of his/her investment and attempt when learning foreign language. This is an important factor to affect motivation and autonomy as every learner wants to see the progress of learning. This progress is assessed by himself/herself or evaluated by other people involved in their learning process. Harklau (2000) in a literature review demonstrated that on-going achievements mutually interacts with self-efficacy to shape learners experience and identity continually in school. This study clarifies and elaborates this argument by identifying that clear achievements is one of the five main constructs to decide learners' central causes of learning success and failure.

\section{CONCLUSION}

Among numerous affecting factors, motivation and autonomy have been widely identified to be the "key" to failure or success when learning a foreign language (Nunan 1988, Cook 2001, Brown 2000, Willing 1989, Oxford 1990; Wenden 1991). Results of this empirical research study not only confirms the role of these two central factors but also arranges them into a united and holistic model that reflects their internal, mutual, peripheral, and flexible relationship with other outer affective constructs. It is not really because of any single change in any sole construct, but the operation of this whole model shapes the success and failure in learning a language. This model addresses that motivation and autonomy have a mutual relation and are the two most central and influential constructs. Besides, they are also the two most stable constructs in this continuously changing model. Motivation and Autonomy will not change until the closest outer constructs have changed. In contrast, there are a number of factors allocated in the outer zone, and these factors are much more ready to changes and influences. In other words, the changes of outside lead to changes of inside and finally, changes of the central constructs. Therefore this model constantly shaped and reshaped, continually recreated and negotiated.

There are certain limitations of this study like the variation of the samples. Strauss and Corbin (1990) suggest that samples in grounded theory are better when they reflect as much variation as possible. However, to ensure an in-depth collection of qualitative data, number of participant in this study was enough to meet credibility and reliability criteria of a grounded theory research.

\section{REFERENCES}

[1] Bandura, A. (1989). 'Regulation of cognitive processes through perceived self-efficacy'. Developmental Psychology, 25, 729-735.

[2] Brown, H. D. (1991). Breaking the language barrier: Creating your own pathway to success. Intercultural Press. 
[3] Brown, H. D. (2000). Principles of language learning and teaching. White Plains, NY: Longman.

[4] Charmaz, K. (2000). Grounded theory: objectivist and constructivist methods. In Denzin, N. K. \& Lincoln, Y .S. (2000). Handbook of qualitative research, Sage Publications, 509-536.

[5] Colquitt, J. A. \& Simmering, M. J. (1998). 'Conscientiousness, goal orientation, and motivation to learn during the learning process: A longitudinal study'. Journal of Applied Psychology, 83(4), 654-665. DOI: 10.1037/0021-9010.83.4.654

[6] Cook, V. (2001). Second language learning and teaching. London: Arnold.

[7] Ehrman, M., \& Oxford, R. L. (1995). 'Cognition plus: Correlates of language learning success'. Modern Language Journal, 79, 67-89. DOI: 10.2307/329394

[8] Ellis, G. \& Sinclair, B. (1989). Learning to learn English: A course in learner training. Cambridge University Press.

[9] Glaser, B. \& Strauss, A. L. (1967). The discovery of grounded theory: Strategies for qualitative research. Aldine Publishing Company, New York.

[10] Glaser, B. (1978). Theoretical sensitivity. Sociological Press, Mill Valley, CA, USA.

[11] Glaser, B. (1998). Doing Grounded theory: Issues and discussions. Sociology Press, Mill Valley, CA, USA.

[12] Glaser, B. (1992). Basics of grounded theory analysis. Sociology Press, Mill Valley, CA, USA.

[13] Guiora, A. Z. (1983). 'The dialectic of language acquisition. In A.Z. Guiora (Ed). An epistemology for the language sciences'. Language Learning 33, 8-13. DOI: 10.1111/j.1467-1770.1984.tb01321.x

[14] Griffiths, C. (2008). Lessons from good language learners. Cambridge University Press.

[15] Graham, S. (2006).' A study of students' metacognitive beliefs about foreign language study and their impact on learning'. Foreign Language Annals, 39, 296-309. DOI: 10.1111/j.1944-9720.2006.tb02267.x

[16] Harklau, R. (2000). "From the "good kids" to the "worst": Representations of English language learners across educational settings'. TESOL Quarterly, 34(1), 35-67. DOI: 10.2307/3588096

[17] Horwitz, E. K.; Horwitz; M. B.; \& Cope, J. (1986). 'Foreign Language Classroom Anxiety'. The Modern Language Journal, 70(2), 125-132. DOI: 10.2307/327317

[18] Kormos, J. (2012). 'The role of individual differences in L2 writing'. Journal of Second Language Writing, 21(4), 390-403.

[19] Kormos J.; Kiddle, T.; \& Csizér, K. (2011). Systems of Goals, Attitudes, and Self-related Beliefs in SecondLanguage-Learning Motivation. Applied Linguistics, 32 (5), 495-516.

[20] Krashen, D. The input hypothesis. In Alatis, J. E. (1980). Current issues in bilingual education. Georgetown University Press, 168-80.

[21] Magogwe, J. M., \& Oliver, R. (2007). 'The relationship between language learning strategies, proficiency, age, and self-efficacy beliefs: A study of language learners in Botswana'. System, 35, 338-352.

[22] McKay, S. L., \& Wong, S. C. (1996). 'Multiple discourses, multiple identities: Investment and agency in second-language learning among Chinese adolescent immigrant students'. Harvard Educational Review, 66, 577-608.

[23] Norton, B. (1997). 'Language, identity, and the ownership of English'. TESOL Quarterly, 31, 409-429. DOI: $10.2307 / 3587831$

[24] Nunan, D. (1988). The learner centered curriculum. Cambridge University Press.

[25] Oxford, R. L. (1990). Language Learning Strategies: What Every Teacher Should Know. Newbury House.

[26] Peirce, B. N. (1995). 'Social identity, investment, and language learning'. TESOL Quarterly, 29, 9-31. DOI: $10.2307 / 3587803$

[27] Pintrich, P. R. (2000). The role of goal orientation in self-regulated learning. In Boekaerts, M. Pintrich, P. R. (Ed), Zeidner, M. Handbook of self-regulation. Academic Press, San Diego, CA, US. 
[28] Porte, G. (1988). 'Poor language learners and their strategies for dealing with new vocabulary'. ELT Journal, $42(3), 167-172$

[29] Reiss, M. A. (1981). 'Helping the unsuccessful language learner'. The Modern Language Journal, 65(2), 121128. DOI: 10.1111/j.1540-4781.1981.tb00960.x.

[30] Rubin, J. (1975). 'What the "good language leaner" can teach us'. TESOL Quarterly, 9(1), 41-51. DOI: $10.2307 / 3586011$

[31] Rubin, J. \& Thompson, I. (1994) How to Be a More Successful Language Learner. Beijing: Foreign Language Teaching and Research Press.

[32] Scovel, T. (1978). 'The effect of affect on foreign language learning: A review of the anxiety research'. Language Learning, 28, 129-142. DOI: 10.1111/j.1467-1770.1978.tb00309.x

[33] Stern, H. H. (1983). Fundamental Concepts of Language Teaching. Oxford: Oxford University Press.

[34] Strauss, A. \& Corbin J. (1990). Basics of qualitative research: Grounded theory procedures and techniques. Sage Publications.

[35] Strauss, A. \& Corbin, J. (1994). 'Grounded theory methodology: an overview'. In Denzin N. K. \& Lincoln Y.S. Handbook of Qualitative Research, Sage Publications, 273-285.

[36] Strauss, A. \& Corbin, J. (1998). Basics of qualitative research: Techniques and Procedures for Developing Grounded Theory. Sage Publications.

[37] Takeuchi, O. (2003). 'What can we learn from good foreign language learners? A qualitative study in the Japanese foreign language context'. System 31, 385-392.

[38] Watson, D. \& Friend, R. (1969). 'Measurement of social-evaluative anxiety'. Journal of Consulting and Clinical Psychology, 33, 448-51.

[39] Vuong, M.; Brown-Welty, S.; \& Tracz, S. (2010). 'The effects of self-efficacy on academic success of firstgeneration college sophomore students'. Journal of College Student Development, 51, 50-64.

[40] Wenden, A. L. (1991). Learner strategies for learner autonomy. Hemel Hempstead, UK: Prentice Hall.

[41] Williams, M. \& Burden, R. L (1997). Psychology for Language Teachers. Cambridge University Press.

[42] Willing, K. (1989). Teaching how to learn: learning strategies in ESL. National Centre for English Language Teaching and Research, Macquarie University

\section{HỌC NGOẠI NGŨ̃: PHÍA SAU NGUYÊN NHÂN THÀNH BẠI}

Tóm tắt. Trong khi nhiều nghiên cứu đã chứng minh người thành công và không thành công trong việc học tiếng Anh đã hoặc đang học như thế nào, nghiên cứu này đi tìm quá trình tiến bộ hoặc thụt lùi của người học; từ đó cung cấp cái nhìn khách quan và tổng thể về những yếu tố tác động lên quá trình này, sự biến đổi không ngừng của những yếu tố tác động từ bên ngoài và cả những yếu tố bị tác động trong chính bản thân người học, đặc biệt là kiến thức và kỹ năng, trong quá trình học tập. Áp dụng phương pháp nghiên cứu Xây dựng Lý thuyết trong nghiên cứu định tính, phương pháp quan sát, phỏng vấn để lấy dữ liệu định kỳ trên 8 sinh viên ngành Ngôn ngữ Anh trong 24 tháng, tác giả đã xây dựng được một mô hình để lý thuyết hoá về quá trình biến đổi về kiến thức, kỹ năng của người học ngôn ngữ này.

Từ khoá. grounded theory, achievement and failure, motivation, autonomy, affective factors.

Ngày nhận bài: 14/12/2017

Ngày chấp nhận đăng: 18/01/2018 